\title{
RUNES TRANSCRIBED FROM DIG SITE 401A IN LADYSMITH, WISCONSIN
}

\author{
Postcards from the past.
}

\section{BY RACHAEL K. JONES}

Dear Joel,

I fell into the sinkhole when I arrived. Soaked head to toe, and the nearest laundromat 10,000 years away.

Stupid me.

I remember what you said: only the hard parts survive. Just the bones fossilize, while the soft bits rot away. So I'm writing all this down on long, columnar bones because I have to tell you about it, even in this somewhen unanticipated on my quick submersible dip. No experience is complete until I share it with you.

I mean it.

I ate a baby camelops for dinner. I killed it with my handgun. In retrospect I should've saved the bullet.

Oh well.

You don't see camelops in Wisconsin these days. (Your days, I mean. Future days.) Maybe I'm the reason?

Sorry for extincting your camelops, Joel.

Anyway, I miss you.

Suzanne

Joel,

It took me six years, but I found the wormhole that brought me here, bubbling modern fossils and anachronistic plastic. I sprained my ankle tumbling down the muddy bank that sheltered it. Damn it all. It hurts so bad. I wish they'd hurry up and invent morphine.

I could try to take the wormhole home, but I'm too afraid. It's all pressure on the other side. Going through without a functional submersible might pancake me.

I'm inventing an alphabet to pass the time, carved on a giant armadillo's scales. (They taste like ass, FYI.) It's a shame you won't get to see my notebook, all my sketches, the tracings of leaves, the feathers glued to sap. Only the hard parts survive, and all.

I'm not a hard thing, you know. I cave under too much strain. It's why I never went to med school. But I can carve lines with a

$\rightarrow$ NATURE.COM

Follow Futures:

@ @NatureFutures

$f$ go.nature.com/mtoodm pocket knife, chuck these bones into the sinkhole, and hope.

I lied about the alphabet, by the way.

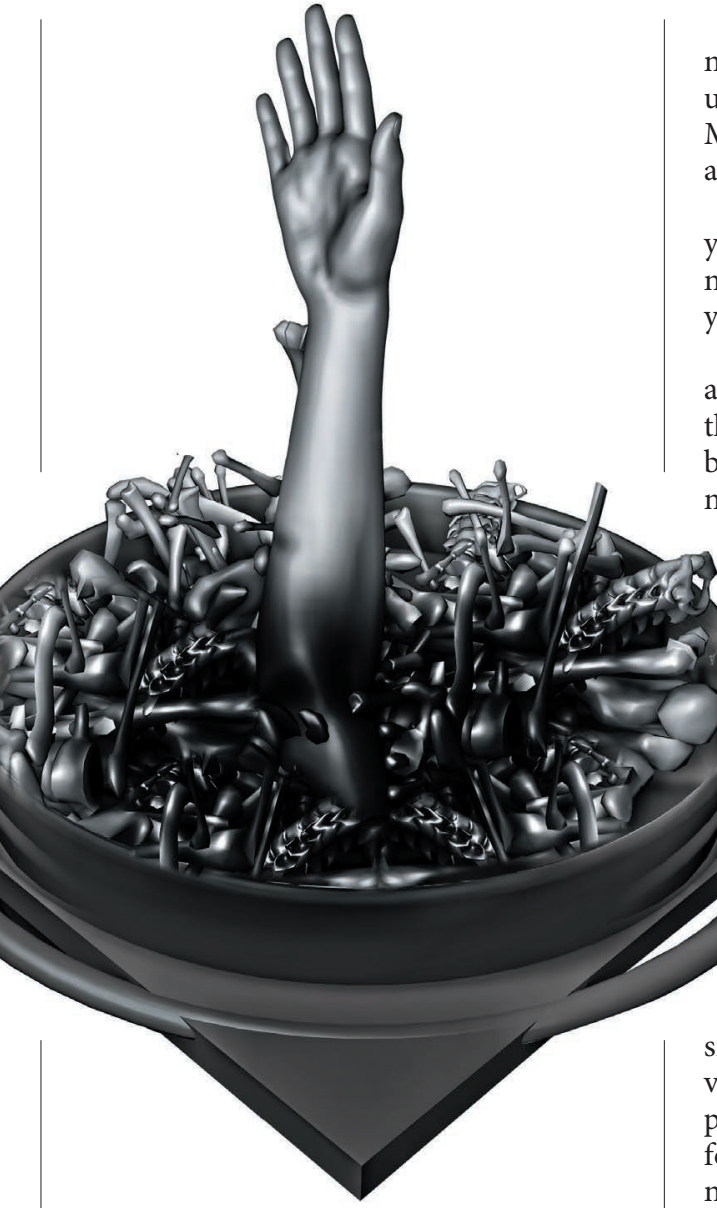

I found another thing: coxal bone fragments, some vertebrae, a scapula and an ulna with a long-healed hairline fracture. Male and Homo sapiens sapiens, or I'm no anthropologist. My first visitor in ten years.

You broke your arm once as a kid, didn't you Joel? What went wrong with your submersible? I wish you could tell me. I miss you more than ever now.

It's 10,000 years until you'll exist, and after a decade of early Holocene, I've realized there will never be a good time to lose your best friend, no fullness of days that would make it right. Life will always be too short for us, Joel.

So I've decided not to wait any longer. It's my turn to rescue you. I'm patching up the old submersible tonight. Let's just pray it'll survive a final trip.

Maybe time bends on each end. Maybe I'll arrive before leaving, return your hip to you, and apologize for our spat. I've saved you so many hugs. Tomorrow I'm going for a swim. Tomorrow I'm riding the timestream home. I'll be the only woman in Wisconsin who's eaten a baby camelops. Or at the very least I'll make a cool exhibit. They'll probably rename me, interrogate my molars for my taco recipe, measure my hips for nonexistent daughters. I'll muck up all the scholarship about Dig Site 401A for the next century.

There are worse ways to be remembered.

As for me, I've learned to survive, hard as any fossil. Oil forms from living things crushed by time and pressure. Cram enough existence into one space and it all blurs: Suzanne and Joel, human and camelops, our somewhens and somewheres inseparable.

When you're born, I'll have always existed down in the sinkhole, the fossil firing your young dreams. Whatever happens, I'm not gone, Joel. I'm waiting in your past, your future. I made it through once. I'll make it again.

Look for me 10,000 years tomorrow, rising among the bones.

Yesterday, the wormhole produced a range of submersible parts - everything I needed to make repairs. Welded onto the panels, I read: Camelops Extinction Prevention Squad. In futhark, of course.

Real funny, Joel.
Rachael K. Jones is an author, editor, and secret android. Her fiction has appeared in dozens of magazines. She lives in Portland, Oregon, with her husband. 